\title{
ZBIGNIEW KAPROÑ
}

\section{MUZEUM DIECEZJALNE SZTUK! RELIGITISJ W LUBLINIE}

Muzeum Diecezjalne w Lublinie istniało kilka lat w okresie międzywojennym. Zgromadzone tam eksponaty nie przetrwały jednak okupacji. Obecne Muzeum powstało z inicjatywy i starania obecnego Ordynariusza lubelskiego J. E. K.s. Bpa Bolesława Pylaka. Jeszcze jako Biskup Sufragan widział potrzebę utworzenia takiej instytucji przy Kurii Biskupiej i zobowiązal swoich współpracowników do organizowania zaplecza pod przyszła placówkę. Ostatecznie otwarcie Muzeum potwierdził dekret K.s. Bpa Ordynariusza z dnia 26 sierpnia 1975 roku. Otrzymało ono wtedy kilka pomieszczeń w budynku przy ul. Podwale 15 . Jednocześnie na mocy decyzji $K_{\text {s. }}$. Biskupa $w$ organizm Nuzeum weszła Wieża Trynitarska pozostając dalej dzwonnicą katedralną.

Większość muzeów diecezjalnych istniejących w Polsce gromadzi najcenniejsze dzieła sztuki sakralnej $\mathrm{z}$ danego terenu dla celów ekspozycyjnych. Sa one wyrywane z kościoła, choć mogłyby tam jeszcze funkcjonować. Specyfika naszego Muzeum od samego początku polegała na trosce i pracy profilaktycznej zmicrzającej do zabezpieczenia najwartościowszych obiektów $w$ terenie - w ich naturalnym kontekście historycznym. Sama ekspozycja była dla nas i jest obecnie sprawą drugoplanowa. Nie oznacza to wcale, że poniechaliśmy $w$ ogóle ekspozycji. Wiadomo bowiem, że z muzeum łączy się jakieś polrazywanie zabytlków. Do tego potrzebne były pomieszczenia. Przekazana nam Wieża Trynitarska częściowo zaspokoiła te potrzeby. Zdajemy sobie sprawę, że Muzeum nasze jest ciągle w stadium rozwoju. Czeka nas dalszy trud jego tworzenia.

Prace przy Wieży trwały cztery lata i realizowane były w kilku eta: pach. Najpierw dokonano remontu elewacji i hełmu. Prace te wykonała parafia katedralna. Dwa lata prowadzone były intensywne prace we wnętrzu oraz ostatni etap na przestrzeni roku dotyczył przygotowania i umieszczenia obiektów ruchomych czyli wyposażenia. Prace te wylkonali studenci historii sztuki Katolickiego Uniwersytetu Lubelskiego pod kierunkiem ks. prof. Władysława Smolenia.

Przy realizacj̧i prac kierowaliśmy się zasadą: uszanować zabytkowy charakter wnętrza, zastana monumentalną konstrulscję drewnianą, a jednocześnie stworzyć warunki dla umieszczenia zabytków i uczynić Wiezę dosteppna dla zwiedzających.

Przed przystapieniem do prac remontowo-adaptacy jnych dokonaliśmy wszechstronnych badan Wieży: architektonicznych, wytrzymałościowych, mikologicznych, dokonaliśmy pełnej inwentaryzacji Wieży. Biorąc pod uwagę koszty całego remontu adaptacyjnego, jak i własne możliwości finansowe postanowiliśmy realizować prace systemem gospodarczym. Wy- 
konaliśmy cały szereg prac zarówno ciesielsko-stolarskich, jak i murarskich i ślusarskich. Wyremontowaliśmy wszy stkie stropy', większośc okien wymagała wymiany, całkowicie zostały wymienione schody i podprowadzone $\mathrm{w}$ nowy sposób, bardziej funkcjonalny. Założyliśmy nową instalację elektrycznas, nagłośnienie, oszkliliśmy wszystkie okna. Wykonaliśmy dezynfekcję i impregnację calej konstrukcji drewnianej. Aby wykonać tak rozległe prace, musieliśmy pokonać wiele przeszkód, jeśli nie wspomnieć klopotów finansowych. Gdyby nie fakt, że sprawie tej patronowal sam $\mathrm{Ks}$. Bp Ordynariusz, na pewno nie dalibyś́my rady. Myślimy jednak, że trud ten opłaciło się ponieść. Od momentu otwarcia do dnia dzisiejszego przewinęlo się przez Wieżę około 250000 zwiedzających, w tym większość w grupach zorganizowanych. Zorganizowaliśmy również 18 wystaw czasowych, ukazując przez nie wkład Kościoła w kulturę polską. Pragnęliśmy stworzyć pewną odmienność, nadać inny charakter, aby $\mathrm{w}$ Wieży przewijała sie atmosfera religijności, skupienia i zadumy. Stąd też specyficzny podkład muzyczny, który towarzyszy zwiedzającym, półmrok w miejscach szczególnych, a także objaśnienia przewodników zwracających uwage, głównie młodzieży, na wkład Kościoła w ratowanie zabytków.

Záłożeniem Muzeum było, aby pracownia konsérwatorska służyła całej diecezji, wykonując prace solidnie i tanio.

Od początku działalności podjęliśmy również zadanie kompletowania kari inwentaryzacyjnych wszystkich obiektów sakralnych ruchomych $\mathrm{w}$ diecezji. Prace te wykonujemy przy współpracy Biur Dokumentacji Zabytków, głównie Lublina i Zamościa.

Od roku $1978 \mathrm{w}$ nowym składzie osobowym pracowni konserwatorskiej zaczęliśmy konserwować śmielej i sprawniej nowe obiekty, niekiedy bardzo trudne, o dużej randze historycznej. Wykonaliśmy peiną konserwacje kaplicy Górskich i kaplicy Borkowskich w Farze w Kazimierzu Dolnym, czterech oltarzy w kościele św. Agnieszki w Lublinie, ołtarza w Kolegiacie Zamojskiej, 3 ołtarzy z Bystrzycy, wielu obrazów i rzeźb. Trudności $\mathrm{w}$ zaopatrzeniu $\mathrm{w}$ materiały konserwatorskie, jakie wystąpily w początkach lat osiemđziesiątych, przezwyciężyliśmy sprowadzając je z zagranicy.

Uwieńczeniem ukazującym nasze możliwości, zarówno pod względem fachowym jak i organizacyjnym, była konserwacja, bardzo dużego powierzchniowo $i$ bardzo trudnego $w$ pracỳ, głównego ottarza $w$ katedrze lubelskiej.

Reasumując wykonaliśmy na przestrzeni tych minionych lat pełną konserwację ponad 200 obiektów, w tym: stu pięćdziesięciu obrazów olejnych na płótnie, desce lub blasze, 10 ołtarzy, 10 rzeźb i feretronów, 2 ambony, 10 mebli. Wykonano ponadto zabiegi zabezpieczające, dezynfekcję, impregnację, podklejanie, zabezpieczenie lica na około stu obielztach znajdujących się w zbiorach Muzeum. mebli.

Od kilku lat dziala przy Muzeum pracownia renowacji zabytkowych

Wychodząc naprzeciw istniejącemu zapotrzebowaniu, Muzeum stworzył ło podwaliny i zapoczątkowało działalność Duszpasterstwa Srodowisk Twórczych w Lublinie. 